\title{
Sheffield Steel
}

$\mathrm{T}$ HE intimate association of Sheffield with the steel industry is probably even better known and appreciated than the proverbial relationship between coals and Newcastle. In the former case the industry has developed practically from its very birth within this city to its present unshakable and unique position in the industrial world, and although steel-making in England is now rather more decentralised than was formerly the case, Sheffield still holds pride of place in respect of both historical associations and present-day importance.

The rise of Sheffield as a metallurgical centre may be attributed in part to certain natural advantages and to the gradually accumulated skill of generations of craftsmen of the city, but preeminently it must be ascribed to the important contributions made to steel metallurgy by such men as Huntsman, Bessemer and Sorby. It was here that Benjumin Huntsman, in the years between 1730 and 1740 , conceived the idea of melting the carburised bars of Swedish wrought iron in crucibles, and persevered with his experiments until the practical difficulties associated with this novel procedure were surmounted. The Huntsman method of melting and casting proved a great ad. vance on the methods then in use for the production of shear steel by hammering the bars of carburised wrought iron, and gave a much more uniform and coherent product. From this time onwards to the middle of the nineteenth century, the crucible process of steel-making developed rapidly in Sheffield, and the tool steel produced acquired that reputation for quality and reliability which has characterised all Sheffield products down to the present day.

Some time after the rise of the Huntsman process, it was found possible to combine carburisation and fusion into one operation by melting together a mixture of Swedish wrought iron and charcoal, and, eventually, attempts were made to substitute English wrought iron. The latter procedure was eventually made commercially practicable by the introduction of manganese into steel-making, due to Heath, who in 1839 took out a patent covering the addition to cast steel of manganese in the form of a carbide, prepared

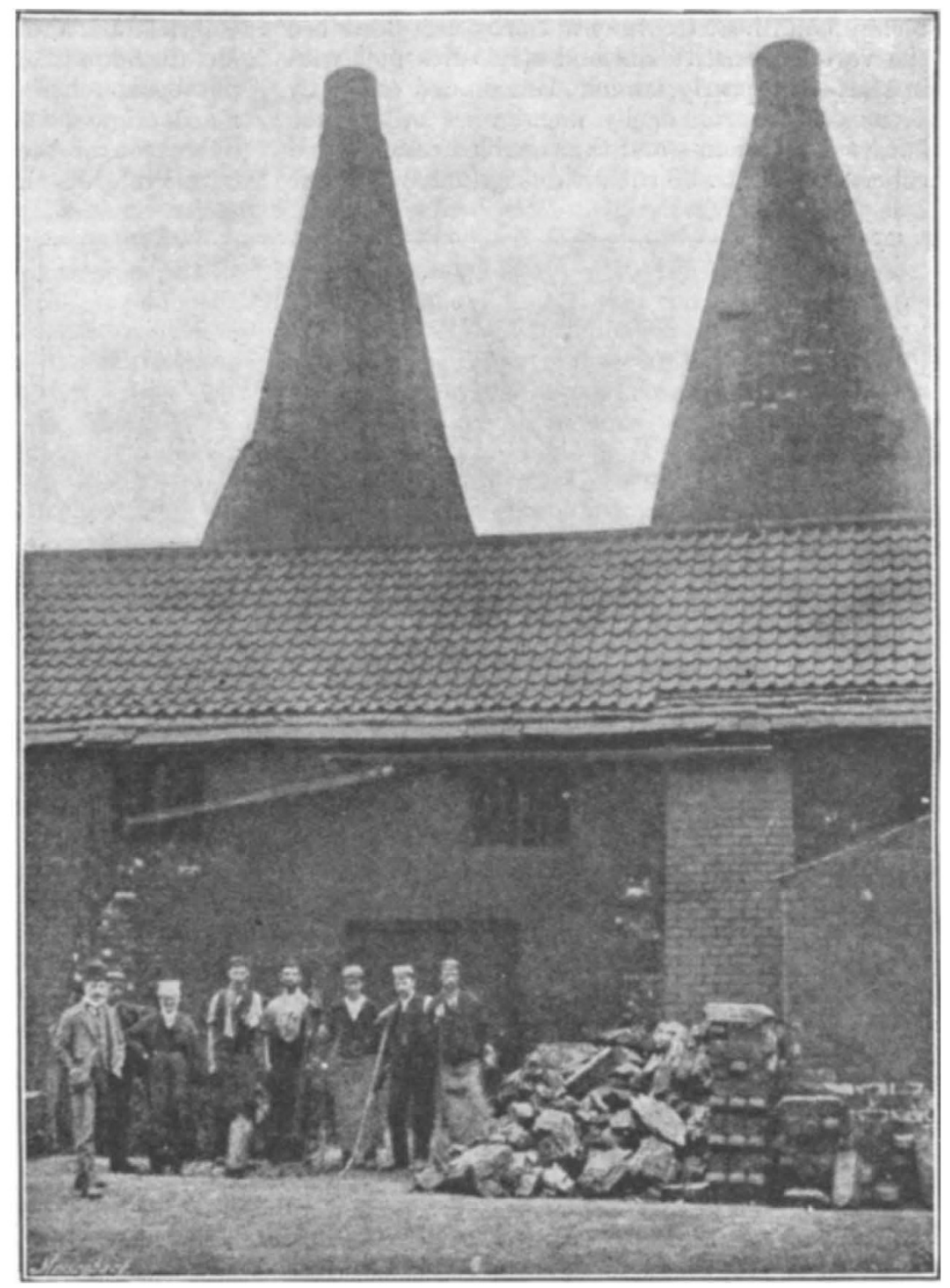

Fit. 1. Huntsman's original works and furnaces. Reproduced by courtesy of Sir Robert Hadfleld.

by roasting manganese dioxide with carbonaceous matter.

Then followed the Bessemer process for the treatment of molten pig iron by blowing air through it. This process, which was put on a commercial footing in Sheffield, made it possible to produce structural steel cheaply and in reasonable quantity. Later came the development of the open-hearth regenerative furnaces by the brothers Siemens, 
working in conjunction with Pierre Martin. The Siemens-Martin method made possible the huge outputs from individual furnaces which have characterised more recent years, and also led the way to the development of the long list of alloy steels now in use for a variety of engineering purposes.

Again, it was a citizen of Sheffield, Henry Clifton Sorby, who devised the microscopic method of examining the structure of metals and laid the foundations of the science of metallography and the technique of heat treatment. Sorby first described the various constituents and structures met with in steel-the pearly laminæ, surrounded either by areas of soft iron or by membranes of a much harder constituent-and thus enabled rational and coherent ideas to be substituted gradually for the

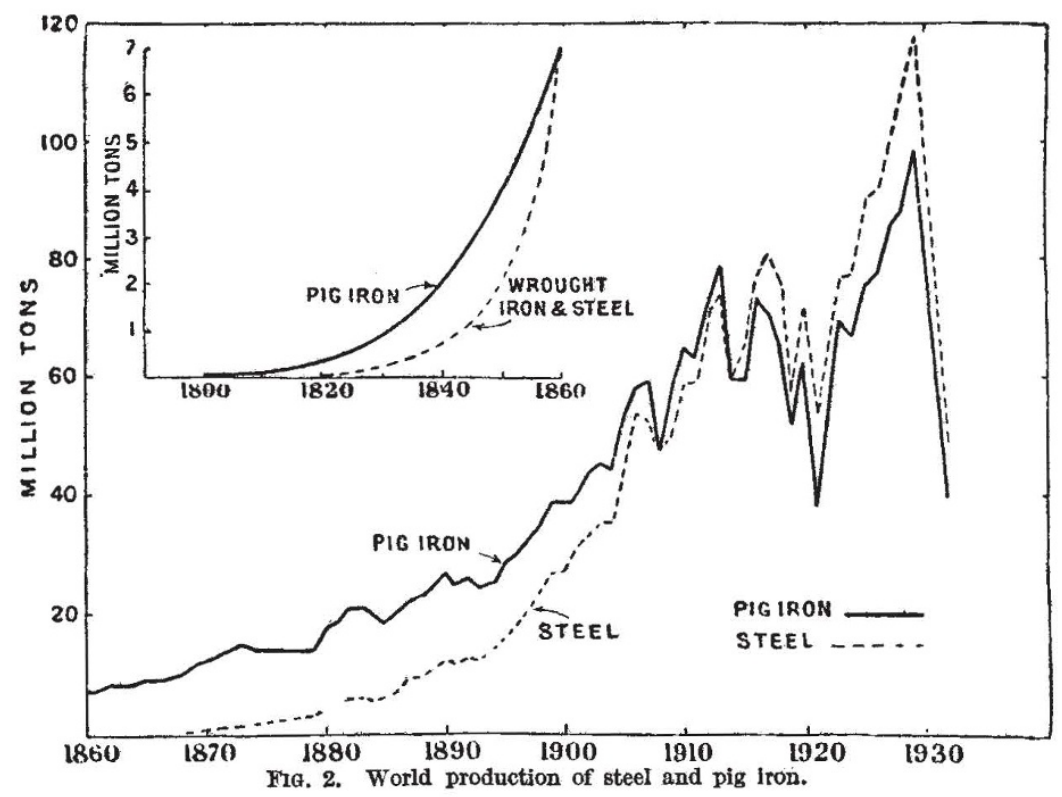

is given of the rise of metallurgical industry, with particular reference to the City of Sheffield, together with a miscellany of historical references and personal reminiscences. Throughout the book stress is laid on our great debt of gratitude to the workers of the past, both inventors and craftsmen, upon whose labours the structure of modern steel metallurgy has been erected.

An interesting account is given of the details of Huntsman's method of manufacturing crucible steel, as witnessed by the French metallurgist, Gabriel Jars, and described by him in his "Voyages Metallurgiques", published in 1774. The historic photograph here reproduced (Fig. 1), of Huntsman's original works and furnaces, gains in interest by reason of the fact that it was taken by the late Prof. J. 0. Arnold, of the University of Sheffield. The following section surveys the rapid expansion which occurred between 1750 and 1850 , owing to the development of the Bessemer process, the Siemens-Martin process, and the basic Bessemer and open-hearth processes. The rise and development of alloy steels are discussed, with particular reference to the Hadfield inventions of manganese and silicon steels. Mention is also made of the newer types of heat and corrosion resisting steels, but surprisingly little is said on the subject of the high duty structural steels for automobile and aircraft purposes, which to-day constitute a considerable proportion of the total output of alloy steels. An interesting diagram, here reproduced (Fig. 2), shows the total world's output of

atmosphere of mystery and secrecy which had surrounded the operations of steel-making.

Two books recently published* place on record much that is of absorbing interest in connexion with the development of the steel industry. Both authors are able to give personal experiences of the steel-making days of more than half a century ago, yet both are still actively interested in modern technique and production methods.

Sir Robert Hadfield's address of welcome to the members of the Iron and Steel Institute who visited Sheffield for the autumn meeting of the Institute is an attractively prepared brochure containing an unique collection of nearly a hundred photographs of past and present metallurgists, and should be of considerable interest and value to those connected with the Sheffield industry or with the University of Sheffield. A vivid sketch

- "Address of Welcome to the Iron and Steel Institute visiting the East Hecla Works of Messrs. Hadfelds, Ltd., on September 14, 1933." Pp. viii + 112. (London: Chapman and Hall, Ltd.) 58 . "Steel-Makers." By Harry Brearley. Pp. xili +156. (London, New York and Toronto: Longmans, Green and Co., Ltd., 1933.) 58. net. steel and pig iron from 1800 down to 1932 .

Succeeding chapters deal with the growth of metallography and heat treatment, the associations of Sheffield with national defence and the manufacture of armaments, and the importance of industrial research. Probably the most interesting section of Sir Robert Hadfield's address is that surveying the development of metallurgical education in Sheffield, and the work of the Faculty of Metallurgy in the University under the successive professors, Greenwood, Arnold, Desch and Andrew. Reference is made to the research department for the cold working of steel, and to the recent project for the establishment of a degree course in foundry work.

Some interesting details are given of the formation of the Iron and Steel Institute in 1869, and of the important part played by the Institute in encouraging research and disseminating knowledge in ferrous metallurgy, and we can heartily commend Sir Robert's advice to all interested in the iron and steel industry to become associated 
with this body. The address closes on a note of encouragement to the younger generation of metallurgists, for whom the future holds in store a wealth of opportunity.

Mr. Harry Brearley's book makes exhilarating reading. His main thesis concerns the value of the judgment and vision of the workman-of the art as opposed to the science of steel-making. This idea is developed with the aid of some pertinent thrusts at the too highly scientific metallographer or chemist, who is apt to use a language which only the initiated can understand and to become unintelligible to those who dutifully read his reports. "There are complaints that what should be, or might be, a clearing house for difficulties is apt to degenerate into a priestcraft able to obscure a difficulty if not explain it."

Mr. Brearley has some hard things to say on the subject of the teaching of metallurgy and the comparative neglect of the process side of steel metallurgy. "And as what the schools call metallurgy turns out to be almost exclusively metallography, there is little wonder that the graduate student comes into the works with notions about the importance of this or that which are sadly out of balance. . . As a supplement metallography is excellent: as a superseder of the older forms of observation and deduction it may not be so excellent-it may be misleading. What a man sees through a microscope is more of less, and his vision has been known to be thereby so limited that he misses what he is looking for, which has been apparent at the first glance to the man whose eye is informed by experience." This leads to views on technical education which are definitely constructive, and a very interesting and attractive suggestion is put forward for the teaching of steel metallurgy under industrial conditions.

Mr. Brearley's book is in part autobiographical, dealing with the author's early days as a cellar. lad in a tool-steel furnace-an occupation he entered at the age of eleven or twelve-with the intimate details of the crucible process as practised in Sheffield in the 'eighties, and with his admiration for the skilled steel-melters with whom he came in contact. "The goodness of the craftsman is in his bones and beats with his blood. The same unruffled confidence, and modesty too, which unfolds itself in men like Faraday unfolds also in humbler workmen; and whilst in them uncouth expression might be mistaken and misunderstood, there are such men whose opinion, muttered in their sleep, is valuable beyond the calculated views of others. Amongst even steel-melters there are 'mute, inglorious Miltons'." $\quad$ L. B. H.

\section{The Asiatic Society of Bengal}

By Dr. L. L. Fermor, O.B.E.

$\mathrm{A}^{\mathrm{s}}$ the Asiatic Society of Bengal is arranging to celebrate on January 15 the one hundred and fiftieth anniversary of its foundation, a short account of its activities will be of interest.

The founder of the Society, Sir William Jones, a Puisne Judge of the Supreme Court at Fort William in Bengal, arrived in Calcutta in 1783. Sir William Jones, who was a distinguished scholar and linguist, soon noticed the want of an organised association as a drawback to progress, and with the co-operation of his friends held a meeting on January 15, 1784, at which thirty gentlemen representing the élite of the European community in Calcutta were present. Sir William Jones delivered a "Discourse on the Institution of a Society for enquiring into the History, civil and natural, the Antiquities, Arts, Sciences, and Literature of Asia" ; and as a result of this address it was resolved to establish a society under the name of the "Asiatick Society". The name adopted for the Society at the inaugural meeting was borme on the records until the close of the fourth decade of the nineteenth century.

In 1829, soon after the foundation-by Henry Thomas Colebrook, a former president of the Asiatic Society - of the Royal Assiatic Society of Great Britain and Ireland in London, and the affiliation of the Literary Society of Bombay with that institution, a letter was received from the Royal Asiatic Society offering to the Asiatic Society in Calcutta the privilege of affiliation, and in this letter the Asiatic Society was for the first time designated as the "Asiatic Society of Bengal". The Society did not accept the affiliation or the change of title, but as the parent of all the Asiatic Societies extant it fitly retained its original name of The Asiatic Society. In 1832, also, when Mr. James Prinsep sought the sanction of the Society to use its name for the journal he was then about to start, the resolution used the words "Asiatic Society" only ; but the editor found it convenient to add a local designation and, in 1843, when the journal became the property of the Society, the new name of Asiatic Society of Bengal had already become familiar and it was formally introduced into the code of by-laws published in 1851. This title has been used continuously since.

This detail concerning title has been deemed necessary because of the confusion that sometimes arises between the titles Asiatic Society of Bengal and Royal Asiatic Society of Great Britain and Ireland, and because it is not always realised that the Asiatic Society of Bengal is the parent and older body.

In his inaugural dissertation, Sir William Jones expounded the definition of the aims of the Society contained in the title of his address and his words have been paraphrased into: "The bounds of its investigations will be the geographical limits of Asia, and within these limits its enquiries 